\title{
Pendampingan Komunitas Masyarakat Sukajadi Dalam Mengedukasi Nilai Guna Sampah Menjadi Berkah
}

\author{
Ida Ida $^{1}$, Ariesa Pandanwangi ${ }^{2}$, Rosida Tiurma Manurung ${ }^{3}$, Nabilla Ayuningtyas ${ }^{4}$ \\ 1,2,3,4 Universitas Kristen Maranatha \\ ${ }^{1}$ Program Studi Manajemen, Fakultas Ekonomi Universitas Kristen Maranatha \\ ${ }^{2}$ Program Studi Seni Rupa Murni, Fakultas Seni Rupa dan Desain Universitas Kristen Maranatha \\ ${ }^{3}$ Program Studi Psikologi, Fakultas Psikologi Universitas Kristen Maranatha \\ ${ }^{4}$ Mahasiswa Program Studi Manajemen, Fakultas Ekonomi Universitas Kristen Maranatha \\ email:ida@eco.maranatha.edu, ariesa.pandanwangi@maranatha.edu, \\ rosida.tm@psy.maranatha.edu, nabillaayuningtyas2@gmail.com
}

Received: 04 March 2021; Revised: 06 June 2021; Accepted: 28 August 2021

DOI: http://dx.doi.org/10.37905/aksara.7.3.833-842.2021

\begin{abstract}
Education of waste management is needed because there are people do not understand how to manage waste. This problem was raised by the government of Bandung in Kang Pisman program (Reduce Separate Benefit). Ikatan kekeluargaan Perempuan Maranatha (IKPM) and Bank Sampah Bersinar support the program by educating the public in improving the use of waste. The target community is the Sukajadi Community. The number of the participants was 45 people. Participants filled out a questionnaire before and after education, 38 participants completed the questionnaire and 7 participants did not complete the questionnaire. Education consists waste sorting, waste management ad types of waste. This service method uses the Participatory Action Research (PAR) method. Wilcoxon Signed Rank Test shows an increase in knowledge about waste sorting, waste management and types of waste. It is hoped that the community from Sukajadi can manage their waste properly and Kang Pisman program can be successful.
\end{abstract}

Keywords: IKPM, Kang Pisman program, community, waste management, Sukajadi

\begin{abstract}
Abstrak
Edukasi manfaat pengelolaan sampah dibutuhkan oleh masyarakat karena terdapat masyarakat yang belum memahami cara pengelolaan sampah. Permasalahan ini diangkat oleh Pemerintah Kota Bandung dalam program Kang Pisman (Kurangi Pisahkan Manfaatkan). Ikatan Kekeluargaan Perempuan Maranatha (IKPM) dan Bank Sampah Bersinar mendukung program tersebut dengan mengedukasi masyarakat dalam meningkatkan guna sampah sehingga menjadi berkah. Masyarakat yang disasar adalah Komunitas Kecamatan Sukajadi. Jumlah peserta sebanyak 45 orang. Peserta diminta mengisi kuesioner sebelum dan setelah kegiatan. Dari 45 peserta, terdapat 37 peserta yang mengisi lengkap kuesioner dan 8 peserta tidak mengisi lengkap kuesioner. Kegiatan yang dilakukan adalah penyuluhan pemilahan sampah, pengelolaan sampah dan jenis sampah yang memberikan nilai guna. Metoda pengabdian ini menggunakan metode Participatory Action Research (PAR). Hasil Wilcoxon Signed Rank Test menunjukkan terjadi peningkatan pengetahuan masyarakat mengenai pemilahan sampah, pengelolaan sampah dan jenis sampah. Diharapkan komunitas dari Kecamatan Sukajadi dapat
\end{abstract}


mengelola sampahnya dengan baik dan benar sehingga program Kang Pisman dapat berhasil.

Kata kunci: IKPM, Kang Pisman program, komunitas, pengelolaan sampah, Sukajadi

\section{PENDAHULUAN}

Indonesia, berdasarkan data Pusat Statistik Lingkungan Hidup, tercatat sebagai negara yang berada dalam kondisi "darurat sampah", khususnya limbah plastik (Varhana, Fajar, Pradipta, \& Ulfah, 2020; Wanda, 2019). Ditengarai bahwa pada tahun 2050 sampah plastik di laut lebih banyak dibandingkan dengan ikan, yakni mencapai 1,6 juta km. Berdasarkan data, sampah plastik di laut telah membunuh 1 juta binatang laut, 100.000 mamalia laut, dan kura-kura di Pulau Seribu (Anonim, 2020). Upaya pembentukan Bank Sampah merupakan upaya kecil yang berdampak besar. Bank Sampah Bersinar (BSB) adalah organisasi di bawah Kementerian Lingkungan Hidup dan Kehutanan, tepatnya Direktorat Pengelolaan Sampah Limbah dan B-3 (Sekarningrum, Sugandi, \& Yunita, 2020). BSB memiliki tugas untuk menumbuhkembangkan dan meningkatkan kesadaran masyarakat, mengubah perilaku masyarakat, serta meningkatkan keterlibatan masyarakat dalam pengelolaan sampah melalui Bank Sampah (Safiah \& Julipriyanto, 2017).

BSB yang terletak di daerah Bojongsoang, Bandung telah menampung tujuh puluh jenis sampah. BSB melakukan kerja sama dengan berbagai retail untuk program "membeli produk; membayar dengan sampah" (Aryenti, 2011; Sekarningrum et al., 2020). Tujuan program ini adalah mengajak masyarakat untuk membangun lingkungan yang bersih, sehat, dan bermanfaat (bernilai ekonomi). Program pengelolaan sampah dengan sistem ini merupakan pola pengelolaan sampah yang telah menggeser pola konvensional kepada pola modern, yaitu sistem perbankan. Jika kita masih dibelenggu oleh pemikiran bahwa sampah berakhir di TPA (Tempat Penampungan Sampah Akhir), sulit sekali untuk membangun lingkungan yang bersih dan sehat (Winahyu, Hartoyo, \& Syaukat, 2019). Pengelolaan sampah dengan sistem Bank Sampah meliputi pengelolaan sampah terpilah dan sampah daur (reduce, reuse, dan recycle) akan berimplikasi kepada berkurangnya sampah di TPA (Kasam, 2011; Rahmadani, 2020). Program Bank Sampah yang telah dilakukan sangat mungkin untuk melibatkan partisipasi dan gerakan masyarakat . Dengan sistem ini, sampah yang dibuang tidak lenyap begitu saja, terjadi perubahan sudut pandang masyarakat terhadap sampah, dan adanya upaya untuk mengubah sampah menjadi produk bermanfaat (Safiah \& Julipriyanto, 2017; Sulistiyorini, Darwis, \& Gutama, 2015). Melalui Bank Sampah, sampah diperlakukan sebagai sahabat yang mendatangkan berkah serta membuat lingkungan asri, bersih, dan sehat. Bank Sampah merupakan gerakan pengelolaan sampah berbasis masyarakat yang melibatkan unit-unit, yaitu Ibu-ibu PKK, Karang Taruna, dan Komunitas Peduli Sampah. Berkat Bank Sampah, terjadi optimalisasi nilai guna sampah.

Masih terdapatnya permasalahan dalam pengelolaan sampah, yakni budaya sikap dan perilaku masyarakat, timbunan dan karakteristik sampah, serta sarana pengumpulan, pengangkutan, pengelolaan dan pembuangan akhir sampah (Sulistiyorini et al., 2015). Pengelolaan sampah di daerah Tunjung Sekar adalah sebagai berikut: 1) Pola pengelolaan sampah sebagian besar masih menggunaakan pola Kumpul Angkut-Buang, (2) Sarana dan Prasarana Pengelolaan sampah tersedia namun belum memadai jika dikaitkan dengan paradigma pengelolaan sampah yang lama (3) Timbulan sampah rata- 
rata sebesar 2,73 L/org.hari atau 0,28 kg/orang.hari (4) Komposisi sampahnya adalah organik basah 60,65\% dan 39,35\% Anorganik. (5) Keterlibatan masyarakat untuk mengelola sampah berbasis 3R cukup signifikan (Sudiro, Setyawan, \& Nulhakim, 2018). Penyuluhan tentang pengelolaan limbah padat sangatlah penting dan warga yang berpendidikan secara signifikan mengalami peningkatan wawasan tentang pengelolaan limbah padat rumah tangga. Pemantauan kegiatan pemilahan sampah rumah tangga juga melampaui target, dengan $100 \%$ petugas pengumpul limbah berhasil mengangkut sampah yang disortir, dan $30 \%$ anggota rumah tangga mengikuti saran penyuluh tentang cara memilah sampah (Zakianis, Koesoemawardani, Fauzia, Asror, \& Ferliana, 2018).

Sampah harus diolah untuk pemertahanan ekosistem, dalam kaitan itu, PkM sejenis terdahulu (Amanah, Damanik, \& Ibrahim, 2014) telah membuat Kelompok Toga di Desa Benteng, Kabupaten Bogor dengan menerapkan prinsip seeing is believing dan working with them. Kelompok Toga ialah kelompok tanaman obat keluarga. Kelompok ini melakukan pendampingan dan pelatihan untuk mengolah sampah organik untuk pupuk tanaman herbal, bersama dengan masyarakat Desa Benteng. Kelompok Toga mengonversi sampah organik dan mengolahnya menjadi kompos. Demikian pula, PkM di Kecamatan Kota Tengah Kota Gorontalo, untuk memberdayakan sampah yang berasal dari limbah menjadi produk bernilai guna, yaitu produk kerajinan. Sampah anorganik dijadikan bahan dasar untuk membuat barang kerajinan yang kemudian dipasarkan melalui media social (Syamsul, Pakaya, \& Muhrim, 2020).

Berdasarkan tinjauan hasil penelitian tentang pengelolaan sampah di atas, penelitian dan pelaksanaan PKM "mengubah sampah menjadi berkah" ini merupakan salah satu pola pengelolaan sampah yang memiliki kekhasan, yaitu menunjukkan adanya gerakan berbasis masyarakat, adanya peningkatan kreativitas masyarakat, dan optimalisasi nilai guna sampah.

\section{METODE}

Keberhasilan dalam pengabdian ini menggunakan strategi untuk mencapai kondisi yang diharapkan, untuk itu dibutuhkan metoda PAR (Participatory Action Research). PAR adalah sebuah metode riset yang dilaksanakan secara partisipatif di antara warga masyarakat dalam suatu komunitas aras bawah yang semangatnya untuk mendorong terjadinya aksi-aksi transformatif melakukan pembebasan masyarakat dari belenggu ideologi dan relasi kekuasan (perubahan kondisi hidup yang lebih baik) (Rahmat \& Mirnawati, 2020).

Dengan demikian, sesuai istilahnya PAR memiliki tiga pilar utama, yakni metodologi riset, dimensi aksi, dan dimensi partisipasi. Artinya, PAR dilaksanakan dengan mengacu metodologi riset tertentu, harus bertujuan untuk mendorong aksi transformatif, dan harus melibatkan sebanyak mungkin masyarakat warga atau anggota komunitas sebagai pelaksana PAR-nya sendiri (Nur Asnawi \& Nina Dwi Setyaningsih, 2021; Soedarwo, Zuriah, Yuliati, \& Suwignyo, 2017).

Metode pengabdian lainnya, adalah metode ceramah, demo dan tanya jawab. Pihak yang terlibat adalah para dosen dari Universitas Kristen Maranatha dan dua orang staf dari bank Sampah Bersinar. Bentuk keterlibatan (patnership) yaitu para dosen menjadi mentor dan pendamping masyarakat dalam kegiatan penyuluhan pemilahan sampah, pengelolaan sampah dan jenis sampah yang memberikan nilai guna. Sedangkan dari Bank Sampah Bersinar memberikan demo tentang pengolahan sampah menjadi nilai guna 
(figure 4. Lokasi kegiatan dilaksanakan di aula kecamatan Sukajadi jalan Sukamulya No. 4 Bandung dengan diikuti oleh 75 orang peserta dari berbagai lapisan masyarakat. Waktu kegiatan (lama proses pendampingan) berlangsung beberapa tahap yaitu pada tahapawal berkoordinasi dengan bank Sampah bersinar sehingga terealisasi pada Nota Kesepahaman No. 013/SKB/DN/UKM/IV/2019 dan Perjanjian Kerjasama No. 018/ PKS/DN/UKM/IV/2019 untuk mewujudkan Go Green Campus. Tahap kedua selanjutnya implementasi di lapangan membuat planing untuk membantu program pemerintah daerah melalui program Kang Pisman. Realisasi kegiatan ini atas ajuan Camat Sukajadi, bapak Yudi Hermawan. Tahap ketiga realisasi di lapangan yaitu melalui survei dan wawancara serta tiga kegiatan yang telah dibahas di atas.

Untuk mengetahui keberhasilan dalam pengabdian ini, peserta diminta untuk mengisi kuesioner yang berisi pertanyaan mengenai pemilahan, pengelolaan dan jenisjenis sampah. Dari 45 peserta yang mengisi kueisoner terdapat 37 kuesioner yang terisi lengkap dan 8 kuesioner tidak terisi lengkap sehingga kuesioner yang diolah adalah 37 kuesioner sebelum edukasi dan 37 kuesioner sesudah edukasi.

Karakteristik peserta berdasarkan usia pada tabel 1 menunjukkan rentang usia peserta yang mengikuti kegiatan ini dari usia 19 tahun sampai 75 tahun.

Tabel 1 Karakteristik Responden Berdasarkan Usia

\begin{tabular}{ccc}
\hline & & Frequency \\
\hline Valid & 19 & 3 \\
& 23 & 1 \\
& 33 & 3 \\
& 39 & 1 \\
42 & 2 \\
& 45 & 3 \\
46 & 2 \\
47 & 2 \\
48 & 4 \\
50 & 2 \\
& 51 & 1 \\
53 & 3 \\
54 & 2 \\
56 & 1 \\
57 & 1 \\
58 & 2 \\
60 & 2 \\
66 & 1 \\
75 & 1 \\
& Total & 37 \\
\hline
\end{tabular}

Karakteristik peserta berdasarkan jenis kelamin pada tabel 2 menunjukkan bahwa jumlah responden Perempuan lebih banyak dari pada Laki- laki. 
AKSARA: Jurnal Ilmu Pendidikan Nonformal

P-ISSN 2407-8018 E-ISSN 2721-7310 DOI prefix 10.37905

Volume 07, (03) September 2021

http://ejurnal.pps.ung.ac.id/index.php/Aksara

Tabel 2 Karakteristik Berdasarkan Jenis Kelamin

\begin{tabular}{lll}
\hline & \multicolumn{2}{c}{ Frequency } \\
\hline Valid & Perempuan & 27 \\
& Laki- laki & 10 \\
& Total & 37 \\
\hline
\end{tabular}

Sebelum menentukan metode analisis data yang akan digunakan maka dilakukan pengujian normalitas. Hasil uji Normalitas dengan menggunakan Metode KolmogorovSmirnov pada tabel 3 menunjukkan bahwa data tidak berdistribusi normal maka dilakukan pengujian dengan menggunakan menggunakan metode Non- Parametrik yaitu Wilcoxon Signed Rank Test.

Tabel 3 Hasil Uji Normalitas One-Sample Kolmogrov-Smirnov

\begin{tabular}{|c|c|c|}
\hline \multicolumn{3}{|c|}{ Dif } \\
\hline $\mathrm{N}$ & & 38 \\
\hline \multirow[t]{3}{*}{ Normal Parameters ${ }^{\mathrm{a}, \mathrm{b}}$} & Mean & 19.7368 \\
\hline & Std. & 20.67925 \\
\hline & Deviation & \\
\hline Extreme & Absolute & .189 \\
\hline \multirow[t]{2}{*}{ Differences } & Positive & .189 \\
\hline & Negative & -.113 \\
\hline Test Statistic & & .189 \\
\hline Asymp. Sig. (2-tailed) & & $.001^{\mathrm{c}}$ \\
\hline
\end{tabular}

Hasil Uji Wilcoxon Signed Rank Test pada tabel 4 menunjukkan bahwa terdapat peningkatan pengetahuan masyarakat mengenai pemilahan sampah, pengelolaan sampah dan jenis sampah.

Tabel 4 Hasil Pengujian Wilcoxon Signed Rank Test

\begin{tabular}{lllll}
\hline & Null Hypothesis & Test & Sig. & Decision \\
\hline 1 & $\begin{array}{l}\text { The median of } \\
\text { differences } \\
\text { between Sebelum } \\
\text { and Sesudah equals } \\
\text { o }\end{array}$ & $\begin{array}{l}\text { Related- } \\
\text { Samples }\end{array}$ & $\begin{array}{l}\text { Wilcoxon } \\
\text { Signed Raject the null } \\
\text { Test }\end{array}$ & \\
\end{tabular}

Asymptotic significances are displayed. The significance level is .05

Tahapan dalam pengabdian ini diawali dengan sosialisasi dan penyuluhan sampah kepada komunitas masyarakat Sukajadi (lihat Fig 1a). Paparan yang disampaikan adalah bahayanya sampah yang kini sangat mengganggu lingkungan sehingga budaya bebas sampah harus terus dimulai dari diri sendiri atau keluarga. Selanjutnya dilakukan brainstorming masyarakat terkait dengan sampah, trainer meminta peserta untuk melakukan yel- yel yang memotivasi masyarakat untuk mengelola sampah dengan baik. 
(lihat Fig 1.b). Kegiatan ini diminati oleh masyarakat dengan adanya diskusi dan tanya jawab. Salah satu pertanyaan yang menarik dari peserta adalah apakah sampah yang diolah dapat meningkatkan ekonomi dalam rumah tangga. Dijawab oleh trainer bahwa pengelolaan sampah tidak hanya meningkatkan ekonomi dalam rumah tangga ternyata setiap sampah yang dibuang memiliki nilai yang berharga (Sahil, Muhdar, Rohman, \& Syamsuri, 2016). Sebagai contoh apabila masyarakat mampu memilah sendiri yang dimulai dari keluarga, sampah plastik berupa botol, gelas dapat ditukar dengan barang kebutuhan pokok (adapun pemilahan dan pengelolaan sampah dapat dilihat fig. 4-5) atau dapat dijadikan tabungan yang bekerjasama dengan salah satu Bank nasional. Acara ditutup dengan penyerahan materi mengenai pengelolaan dan pemilahan sampah. (lihat Fig.3e.).

a

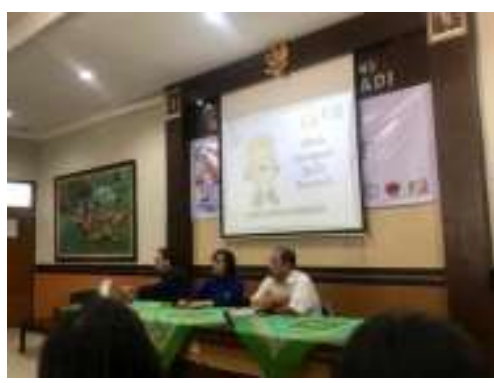

b

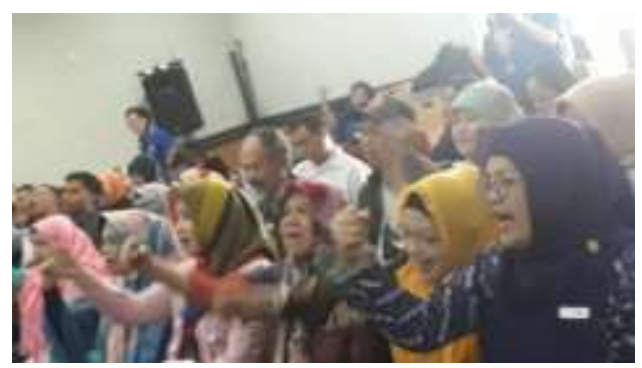

Fg. 1 (a) sosialisasi dan penyuluhan sampah kepada komunitas masyarakat Sukajadi; (b) brainstorming masyarakat terkait dengan sampah

c

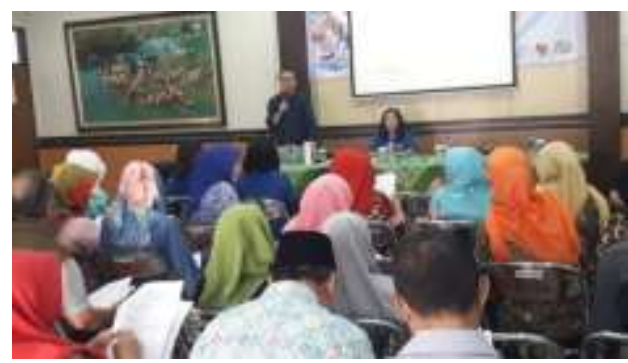

d

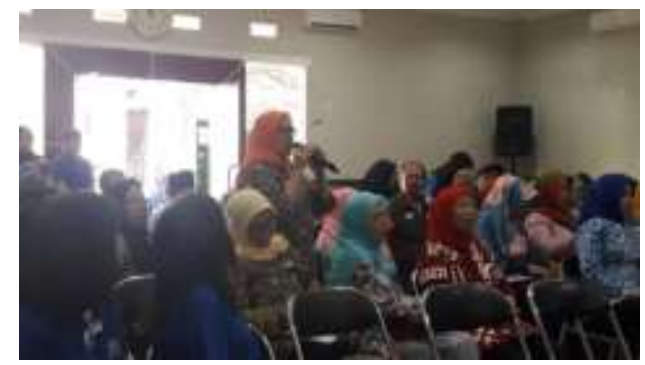

Fg. 2 (c) masyarakat memahami cara mengolah sampah menjadi berkah; (d) masyarakat bertanya soal sampah dan pengelolaannya

e

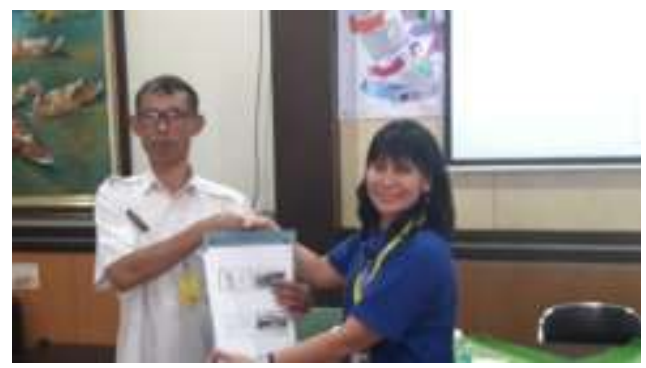

f

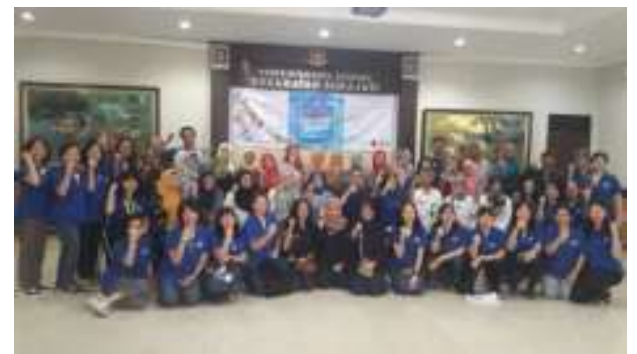

Fg. 3 (e) penyerahan materi secara simbolis kepada kepala bidang lingkungan hidup di Kecamatan Sukajadi;

(f) foto bersama masyarakat setelah pendampingan sosialisasi dan penyuluhan sampah menjadi berkah. 

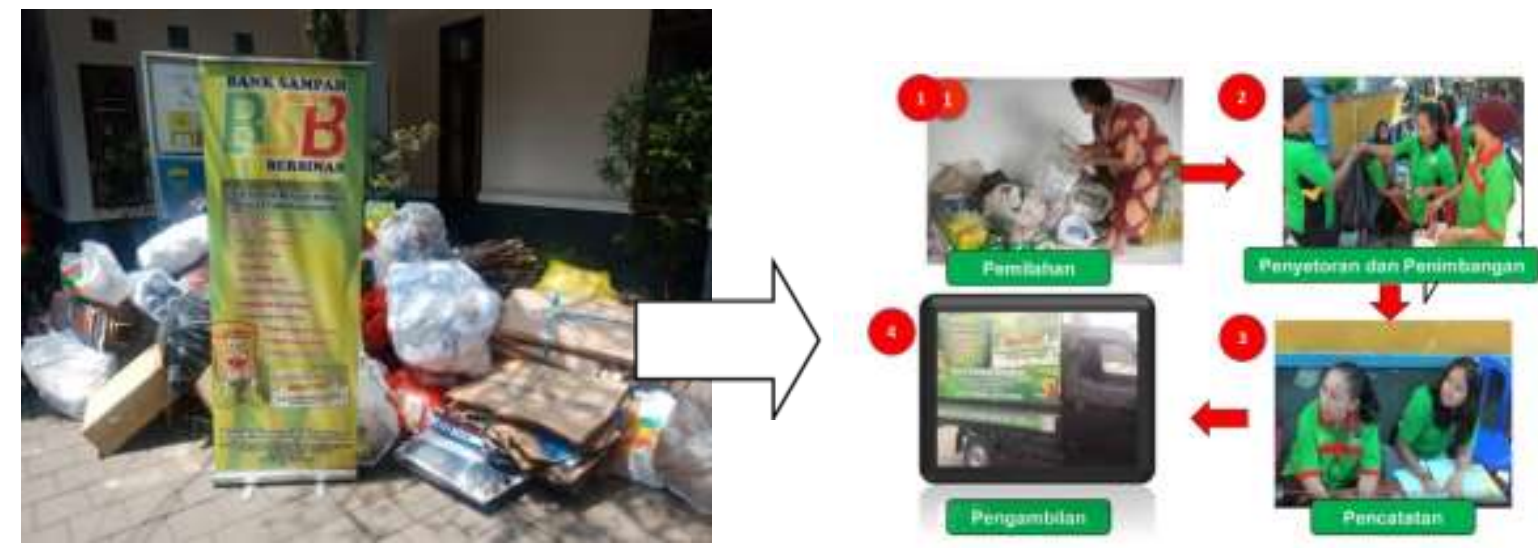

Fg. 4 (g) Pengolahan sampah menjadi berkah.
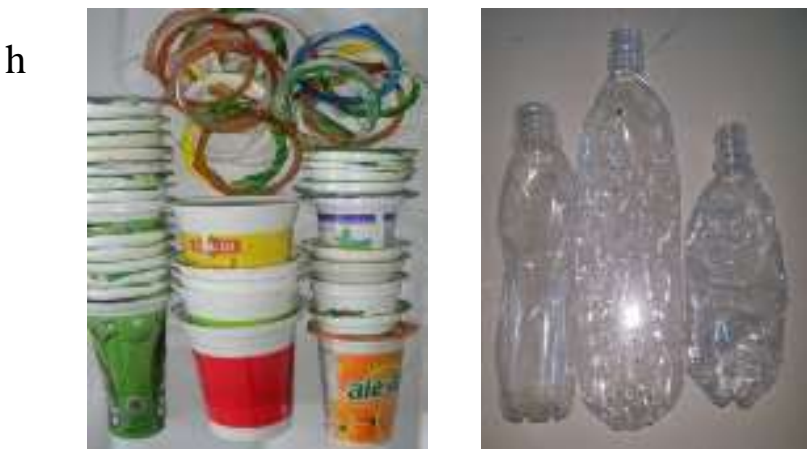

Fg. 5 (h) Contoh Pemilahan Sampah

Sumber: Bank Sampah Bersinar

Berdasarkan paparan di atas dari gambar 1 hingga gambar 5 menunjukkan bahwa gap dari riset ini membuktikan bahwa kegiatan yang dilakukan oleh masyarakat yang bekerja sama dengan BSB berbeda. Hasil dari pengabdian ini meningkatkan kesadaran masyarakat mengenai pengelolaan sampah. Saat ini sebagian masyarakat sudah memiliki tabungan dari hasil sampah, bahkan juga dapat memberdayakan sampah menjadi bagian dari peningkatan ekonomi keluarga.

\section{KESIMPULAN}

Sosialisasi dan pelatihan pemilahan sampah telah berdampak pada terjadinya perubahan perilaku dan cara pandang masyarakat yang menjadi peserta pelatihan untuk mengelola sampah di wilayahnya masing-masing yang dimulai dari keluarga, Temuan penting dari penelitian ini adalah program yang dilakukan oleh komunitas akademik yang bekerjasama dengan BSB dalam mengelola sampah menjadi berkah dapat meningkatkan partisipasi masyarakat dalam Program Kang Pisman yang dicanangkan oleh Gubernur Jawa barat. Hal ini memberikan pengaruh terhadap berkurangnya kebiasaan masyarakat membuang sampah sembarangan. Hal ini juga dibuktikan bahwa masyarakat RW 05 
sudah ketiga kalinya wilayahnya mendapatkan penghargaan sebagai wilayah yang bersih dari sampah.

\section{UCAPAN TERIMA KASIH}

Tim peneliti mengucapkan terimakasih tak terhingga kepada Bank Sampah Bersinar atas kerjasamanya selama kegiatan ini berlangsung. Juga kepada Universitas Kristen Maranatha melalui Ikatan kekeluargaan Perempuan Maranatha yang telah menggerakkan komunitasnya dan mencanangkan program pengabdian kepada masyarakat ini. Semoga kegaiatan yang telah dilaksanakan terus berkelanjutan dan bermanfaat bagi masyarakat.

\section{REFERENSI}

Amanah, S., Damanik, I. P. N., \& Ibrahim, H. (2014). Pemanfaatan Sampah Untuk Mendukung Usaha Tanaman Obat ( Waste Utilisation to Support Herbal Medicine Family Enterprise and Agroecosystem in Benteng Village, Ciampea, Bogor District ) Fakultas Pertanian, Jl Perintis Kemerdekaan Km 9 / 29 , Makassar 9024. Jurnal Manusia Dan Lingkungan, 21(1), 90-97. Retrieved from https://jurnal.ugm.ac.id/JML/article/view/18516/11809

Anonim. (2020). Pada Tahun 2050 Jumlah Plastik di Laut Akan Lebih Banyak Dari Ikan. Retrieved April 12, 2020, from Liputan 6 website: https://environmentindonesia.com/articles/4585/

Aryenti. (2011). Peningkatan Peran Serta Masyarakat Melalui Gerakan Menabung Pada Bank Sampah Di Kelurahan Babakan Surabaya, Kiaracondong Bandung. Jurnal Permukiman, Pusat Litbang Permukiman, 6(1), 40-46.

Kasam, I. (2011). Analisis Resiko Lingkungan pada Tempat Pembuangan Akhir (TPA) Sampah (Studi Kasus: TPA Piyungan Bantul). Jurnal Sains \&Teknologi Lingkungan, 3(1), 19-30. https://doi.org/10.20885/jstl.vol3.iss1.art2

Nur Asnawi, \& Nina Dwi Setyaningsih. (2021). Meningkatkan Perekonomian Masyarakat Melalui Koperasi Syariah: Pendekatan Participatory Action Research. Khidmatuna: Jurnal Pengabdian Kepada Masyarakat, 2(1), 124-143. https://doi.org/10.51339/khidmatuna.v2i1.199

Rahmadani, F. A. (2020). Upaya Menumbuhkan Kesadaran Masyarakat Dalam Menjaga Kebersihan Lingkungan Melalui Pengelolaan Bank Sampah. Comm-Edu (Community Education Journal), 3(3), 261. https://doi.org/10.22460/commedu.v3i3.3482

Rahmat, A., \& Mirnawati, M. (2020). Model Participation Action Research Dalam Pemberdayaan Masyarakat. Aksara: Jurnal Ilmu Pendidikan Nonformal, 6(1), 62. https://doi.org/10.37905/aksara.6.1.62-71.2020

Safiah, S. N., \& Julipriyanto, W. (2017). Manfaat Bank Sampah Bagi Masyarakat Di Dusun Semali Desa Salamkanci Kecamatan Bandongan Kabupaten Magelang. (Study Bank Sampah Semali Berseri). Jurnal REP (Riset Ekonomi Pembangunan), 2(2), 165-184. https://doi.org/10.31002/rep.v2i3.528

Sahil, J., Muhdar, M., Rohman, F., \& Syamsuri, I. (2016). Sistem Pengelolaan dan Upaya Penanggulangan Sampah Di Kelurahan Dufa- Dufa Kota Ternate. BIOeduKASI, 
$4(2), 478-487$.

Sekarningrum, B., Sugandi, Y. S., \& Yunita, D. (2020). Sosialisasi dan Edukasi Kangpisman (Kurangi, Pisahkan dan Manfaatkan Sampah). Kumawula: Jurnal $\begin{array}{llll}\text { Pengabdian Kepada } & \text { Masyarakat, } & 3(1), & \end{array}$ https://doi.org/10.24198/kumawula.v3i1.25244

Soedarwo, V. S. D., Zuriah, N., Yuliati, R., \& Suwignyo. (2017). Pemberdayaan masyarakat melalui pendidikan nonformal berbasis potensi lokal dalam membangun desa wisata adat. Jurnal Sosiologi Pendidikan Humanis, 2(2), 96-102.

Sudiro, Setyawan, A., \& Nulhakim, L. (2018). Model Pengelolaan Sampah Pemukiman Di Kelurahan Tunjung Sekar Kota Malang. Plano Madani, 7(April), 106-117. Retrieved from http://journal.uinalauddin.ac.id/index.php/planomadani/article/view/4894/pdf

Sulistiyorini, N. R., Darwis, R. S., \& Gutama, A. S. (2015). Partisipasi Masyarakat Dalam Pengelolaan Sampah Di Lingkungan Margaluyu Kelurahan Cicurug. Share : Social Work Journal, 5(1), 71-80. https://doi.org/10.24198/share.v5i1.13120

Syamsul, S., Pakaya, S., \& Muhrim, M. (2020). PKM Kelompok Kerajinan Pengolahan Sampah Plastik Di Kecamatan Kota Tengah Kota Gorontalo. JATI EMAS (Jurnal Aplikasi Teknik Dan Pengabdian Masyarakat), 4(2), 79. https://doi.org/10.36339/je.v4i2.328

Varhana, N. A., Fajar, M., Pradipta, F., \& Ulfah, K. (2020). Traceable waste system : konsep pelacakan dan pengelolaan sampah menuju indonesia bersih bebas sampah 2025. Jurnal I lmiahPenalarandanPenelitian Mahas isw A, 4(2), 91-101.

Wanda. (2019). Upaya Indonesia Menanggulangi Limbah Sampah Plastik Dari Belanda. Jom Fisip, 6(1), 1-12.

Winahyu, D., Hartoyo, S., \& Syaukat, Y. (2019). Strategi Pengelolaan Sampah Pada Tempat Pembuangan Akhir Bantargebang, Bekasi. Jurnal Manajemen Pembangunan Daerah, 5(2), 1-17. https://doi.org/10.29244/jurnal_mpd.v5i2.24626

Zakianis, Z., Koesoemawardani, P., Fauzia, S., Asror, M. M., \& Ferliana, E. (2018). The citizens' participation of household solid waste management and monitoring of household solid waste separation in Kelurahan Abadijaya, Kecamatan Sukmajaya, Depok. ASEAN Journal of Community Engagement, 2(2), 221. https://doi.org/10.7454/ajce.v2i2.141 
AKSARA: Jurnal Ilmu Pendidikan Nonformal

P-ISSN 2407-8018 E-ISSN 2721-7310 DOI prefix 10.37905

Volume 07, (03) September 2021

http://ejurnal.pps.ung.ac.id/index.php/Aksara

842 AKSARA: Jurnal Ilmu Pendidikan Nonformal 